Int. J. Electrochem. Sci., 12 (2017) $6404-6416$

\title{
Electrochemical and Surface Investigation of Ni-Cr Glassy Alloys in Nitric Acid Solution
}

\author{
Khadijah M. Emran*, Hanaa AL-Refai \\ Chemistry Department, College of Science, Taibah University, Al-Madinah Al-Monawarah, \\ Kingdom of Saudi Arabia. \\ *E-mail: kabdalsamad@taibahu.edu.sa
}

doi: $10.20964 / 2017.07 .43$

Received: 5 April 2017 / Accepted: 11 May 2017 / Published: 12 June 2017

To understand the corrosion and passivation behaviour of $\mathrm{Ni}_{70} \mathrm{Cr}_{21} \mathrm{Si}_{0.5} \mathrm{~B}_{0.5} \mathrm{P}_{8} \mathrm{C}_{\leq 0.1} \mathrm{Co}_{\leq 1} \mathrm{Fe}_{\leq 1}$ (VZ1) and $\mathrm{Ni}_{72.65} \mathrm{Cr}_{7.3} \mathrm{Si}_{6.7} \mathrm{~B}_{2.15} \mathrm{C}_{\leq 0.06} \mathrm{Fe}_{8.2} \mathrm{Mo}_{3}$ (VZ2) glassy alloys they were studied in nitric acid at different concentrations (1.0- 12.0 M) by AC and DC techniques. Experimental investigations showed that both two alloys spontaneously passivated with a small active region followed by a well-defined passive and transpassive regions at all examined $\mathrm{HNO}_{3}$ concentrations. Critical concentration was observed up to $6.0 \mathrm{M} \mathrm{HNO}_{3}$ for $\mathrm{VZ1}$ alloy and up to $3.0 \mathrm{M} \mathrm{HNO}_{3}$ in the case of VZ2 alloy. Surface morphology was also studied by XPS, SEM, EDS, and AFM techniques after electrochemical measurements. The SEM results showed, deep pit propagation and aggressive surface dissolution with high average roughness values at critical concentration for both two alloys. The inner passive film of $\mathrm{Cr}_{2} \mathrm{O}_{3}$ and outer passive layer of $\mathrm{NiO}$ on VZ1 alloy resulting great resistivity.

Keywords: Ni-Cr glassy alloys, $\mathrm{HNO}_{3}$, Electrochemical study, morphology study.

\section{$\underline{\text { FULL TEXT }}$}

(C) 2017 The Authors. Published by ESG (www.electrochemsci.org). This article is an open access article distributed under the terms and conditions of the Creative Commons Attribution license (http://creativecommons.org/licenses/by/4.0/). 